\title{
Retraction Note: A various soft tissue evaluation of the patients treated by nanocoating orthodontic arch-wires: perceptions in lateral profile photographs and lateral cephalometric radiograps
}

\author{
Nazli Idil Kacamak • Özgür Tosun • Levent Vahdettin
}

Published online: 12 August 2021

(C) Springer Nature B.V. 2021

Retraction Note to: J Nanopart Res (2020) 22:232

https://doi.org/10.1007/s11051-020-04930-7

The Editor-in-Chief and the Publisher have retracted this article. The article was accepted as part of a guestedited special issue in Journal of Nanoparticle Research. Before the special issue was finalized, the Editor-inChief detected problems with editorial handling and peer review and decided not to proceed with the special issue [1].

Post publication peer review found that this article is out of scope for the journal, which focuses on original contributions on nanoscale phenomena and processes, and does not meet the standards required by the journal.
Nazli Idil Kacamak does not agree to this retraction. Özgür Tosun and Levent Vahdettin did not respond to correspondence from the editor or publisher about this retraction.

\section{References}

Pinna, N., Clavel, G. \& Roco, M.C. the journal of nanoparticle research victim of an organized rogue editor network!. J Nanopart res 22, 376 (2020). https://doi.org/10.1007 /s11051-020-05094-0

Publisher's note Springer Nature remains neutral with regard to jurisdictional claims in published maps and institutional affiliations.

The online version of the original article can be found at https://doi.org/10.1007/s11051-020-04930-7

\footnotetext{
N. I. Kacamak $(\bowtie) \cdot$ L. Vahdettin

Department of Orthodontics, Near East University, Nicosia, Turkey

e-mail: nazlidil@gmail.com

Ö. Tosun

Department of Biostatistics, Near East University, Nicosia, Turkey
} 